\title{
Forage Production and Removal from West- ern and Crested Wheatgrasses under Grazing
}

\author{
R.H. HART AND E.F. BALLA
}

\begin{abstract}
Forage production and removal from tillers of western wheatgrass (Agropyron smithii Rydb.) and crested wheatgrass [Agropyron desertorum (Fisch. ex Link) Schult.] were studied at two stocking rates with long-interval time-lapse photography. As stocking rate increased, frequency of grazing increased markedly, but the proportion of available herbage removed at each grazing event increased only in 1977 on western wheatgrass. Forage production per tiller of western wheatgrass was usually higher under light than under heavy stocking, and in one year production of grazed tillers under light stocking was often higher than production of ungrazed tillers. Production per tiller of crested wheatgrass under grazing was marginally less than that per ungrazed tiller, with no difference between stocking rates. Patterns of forage removal with grazing were markedly different from those with clipping, and removal with grazing was much less severe than that imposed in most clipping studies reviewed.
\end{abstract}

Western wheatgrass (Agropyron smithii Rydb.) is the major species in cattle diets in southeastern Wyoming (Samuel and Howard 1982) and presumably in similar range areas. Crested wheatgrass [Agropyron desertorum (Fisch. ex Link) Schult.] is widely used for improved pastures in the West. Therefore, knowledge of the reaction of these species to grazing is important.

Both species evolved under grazing, and properly managed grazing would be expected to do them little harm. Reed and Peterson (1961) reported that, after 13 years of grazing at $0.73,0.93$, and 1.26 $\mathrm{AUM} / \mathrm{ha}$, cover of western wheatgrass was about the same on all pastures but herbage production was 610 and $360 \mathrm{~kg} / \mathrm{ha}$ at 0.73 and 1.26 AUM/ha, respectively. Lewis et al. (1956) found that 4 years of grazing with utilization over $55 \%$ reduced the fraction of total herbage production contributed by western wheatgrass by over $60 \%$ as compared to grazing with utilization under $35 \%$. Klipple and Costello (1960) found that annual herbage production of western wheatgrass was approximately 200,180 , and $40 \mathrm{~kg} / \mathrm{ha}$ after 13 years of 21,37 , and $54 \%$ utilization, respectively. Launchbaugh (1967) studied grazing on native range in Kansas for 20 years at stocking rates of $0.8,1.4$, and 2.0 ha/ yearling steer. In the last 10 years of the study, utilization was 66,49 , and $40 \%$, and production of western wheatgrass was 60,410 , and $1410 \mathrm{~kg} / \mathrm{ha}$, respectively. Thus it appears that even moderate grazing may reduce herbage production of western wheatgrass.

Several studies have shown that herbage production of western wheatgrass is greatly depressed by clipping. When western wheatgrass was clipped four times at 3-week intervals, production was 16 and $59 \%$ less than that of an unclipped control at stubble heights of 10 and $2.5 \mathrm{~cm}$ respectively (Everson 1966). Branson (1956) clipped

\footnotetext{
Authors are research agronomist U.S. Dep. Agr., Agr. Res. Serv., High Plains Grasslands Res. Sta., 8408 Hildreth Koad, Cheyenne, Wyo. 82009; and range scientist, Range Management Administration, P.O. Box 199, Khartoum, Sudan. The research was conducted at the HPGRS while Balla was a graduate assistant, Range Science Dep., Colorado State Univ., Fort Collins 80521.

Manuscript received October 3, 1980.
}

western wheatgrass to $2.5 \mathrm{~cm}$ every 2 or 4 weeks for 14 weeks and found herbage production was reduced 80 and $60 \%$, respectively, below that of unclipped stands. Santos and Trlica (1978) reduced forage production below that of an unclipped check by 75 and $50 \%$ by clipping to a $5-$ or $10-\mathrm{cm}$ stubble every 2 weeks for 24 weeks. Furthermore, when Buwai and Trlica (1977) clipped western wheatgrass $1-3$ times annually for $1-3$ years, herbage production in the fall after the last clipping was depressed $69-97 \%$ below that of an unclipped check.

Clipping may similarly decrease forage production of crested wheatgrass. Carter and Law (1948) found that clipping to a $2.5-\mathrm{cm}$ stubble every 15 or 30 days for 20 weeks reduced herbage production below that of an unclipped check by 51 and $18 \%$, respectively. Bedell (1973) reported that clipping crested wheatgrass at or before the 3-leaf stage did not depress total herbage yield below that of grass cut after maturity, but forage yield was depressed more and more as cutting was delayed after the 3-leaf stage.

These findings indicated that western and crested wheatgrasses are adapted only to light or infrequent grazing, and/or that clipping experiments do not really simulate what happens to grasses under grazing. To evaluate these hypotheses, it is necessary to determine the frequency and intensity of forage removal from grasses under grazing. Greenwood and co-workers $(1968,1974)$ and Hodgson and Ollerenshaw $(1966,1969)$ have studied ryegrass (Lolium perrene L.) under grazing, and Gammon (1978) and Gammon and Roberts (1978) have studicd grazing of native plants on the African veld. However, their techniques require frequent and intensive measurements of individual plants, with considerable disturbance of the stand. Hart (1970) pioneered the use of photography for nondestructive estimates of grazing effects on individual plants. Springfield (1974) later used the same technique to study forage production and utilization of shrubs, and Schmutz et al. (1963) had used photography to estimate stand utilization. We decided to use long-interval time-lapse photography to determine the frequency and intensity of forage removal and to estimate forage production of individual tillers of western and crested wheatgrass under two intensities of grazing.

\section{Materials and Methods}

Western wheatgrass was studied in two native range pastures at the High Plains Grasslands Research Station near Cheynne, Wyo. The range was a typical mixed-grass prairie, developing under an average annual precipitation of about $35 \mathrm{~cm}$. Herbage production in 1976 and 1977 was 970 and $1020 \mathrm{~kg} / \mathrm{ha}$, respectively, of which about $22 \%$ was western wheatgrass. Four transects, each $25 \mathrm{~m}$ long, were located in each pasture. Transects were moved each year but remained in the same general area. The western wheatgrass tiller nearest each meter mark on each transect was ringed with a plastic poultry leg band $2 \mathrm{~cm}$ in diameter, and the band was wired to a $9 \mathrm{~cm}$ spike driven into the ground to the head. Bands were attached in a regular sequence of red, white, blue, yellow, and green 
to facilitate location of tillers by number along a transect. One hundred tillers of western wheatgrass were marked in each pasture.

Three transects, each $35 \mathrm{~m}$ long, were located in each of two crested wheatgrass pastures and the tiller nearest each meter mark was banded. One hundred five tillers of crested wheatgrass were marked in each crested wheatgrass pasture. Herbage production in these pastures was 2250 and $1940 \mathrm{~kg} / \mathrm{ha}$ in 1976 and 1977 , respectively.

During the grazing season, each crested wheatgrass tiller was photographed weekly and each western wheatgrass tiller was photographed every 2 weeks. Tillers were photographed against a board marked with a $2.5 \mathrm{~cm}$ grid, equipped with dials which were set to the tiller number. We attached a card with the date and transect number to the board. Each time the banded tillers were photographed, 25 unbanded tillers of each grass species were selected to cover a wide range of tiller weights. These tiller were photographed, clipped at ground level, dried, and weighed. By using these photographs of tillers of known dry weights as checks, we were able to estimate the dry weights of the banded tillers at each observation date.

When the tiller was grazed between successive observation dates, the amount removed by grazing was estimated by a modification of Linehan's method (Linehan 1952). We first calculated a regression equation relating the weight of ungrazed tillers to their weight on the preceding observation date. We then used this equation to estimate the weight each grazed tiller might have achieved had it not been grazed. This estimate served as $d$ in the equation.

$$
\text { Forage grazed }=(c-f) \frac{\ln d-\ln f}{\ln c-\ln f}
$$

in which $c$ and $f$ are tiller weights before and after grazing, respectively. This equation incorporates a correction for growth during the period between observations, assuming a logarithmic growth curve. If a tiller is completely removed, $f=0, \ln f=$ minus infinity, and $(\ln d-\ln f) /(\ln c-\ln f)$ becomes essentially unity, so forage grazed $=(c-f)=c$, as $f=0$.

Tillers that were not completely removed during the grazing season were clipped, dried, and weighed at the end of the season, and total forage production was calculated as the final weight plus the total of the estimated weights of forage removed by grazing. Utilization was then equal to the total weight removed by grazing divided by the total forage production.

Pasture sizes, stocking rates, and grazing seasons are shown in Table 1. Native range was grazed by a combination of cow-calf pairs and replacement heifers, while crested wheatgrass was grazed
Table 1. Pasture sizes, stocking rates, and grazing seasons.

\begin{tabular}{|c|c|c|c|c|}
\hline \multirow[b]{2}{*}{ Pasture and measurement } & \multicolumn{2}{|c|}{1976} & \multicolumn{2}{|c|}{1977} \\
\hline & $\begin{array}{l}\text { Heavily } \\
\text { stocked }\end{array}$ & $\begin{array}{l}\text { Lightly } \\
\text { stocked }\end{array}$ & $\begin{array}{l}\text { Heavily } \\
\text { stocked }\end{array}$ & $\begin{array}{l}\text { Lightly } \\
\text { stocked }\end{array}$ \\
\hline $\begin{array}{l}\text { Crested wheatgrass } \\
\text { Pasture size, ha } \\
\text { Steers/ha } \\
\text { Grazing season }\end{array}$ & $\begin{array}{l}13 \\
1.53 \\
\text { May 17-. }\end{array}$ & $\begin{array}{l}13 \\
1.16 \\
\text { July } 2\end{array}$ & $\begin{array}{l}13 \\
1.63 \\
\text { May } 24\end{array}$ & $\begin{array}{l}13 \\
1.09 \\
\text { July } 5\end{array}$ \\
\hline $\begin{array}{l}\text { Native range } \\
\text { Pasture size, ha } \\
\mathrm{AU} / \text { ha } \\
\text { Grazing season }\end{array}$ & $\begin{array}{l}192 \\
0.22 \\
\text { June 15- } \\
\text { Nov. } 6\end{array}$ & $\begin{array}{l}295 \\
0.12 \\
\text { May } 5 \\
\text { Nov. } 6\end{array}$ & $\begin{array}{l}192 \\
0.20 \\
\text { June } 24 \\
\text { Oct. } 12\end{array}$ & $\begin{array}{l}295 \\
0.11 \\
\text { May } 18 \\
\text { Oct. } 12\end{array}$ \\
\hline
\end{tabular}

by steers. Although the heavily stocked native range pasture was grazed from June 24 to October 12, 1977, tillers were marked and the first photographs were taken July 27 . Thus only 10 weeks of data were available from this pasture in 1977, and comparisons of grazing frequency were made with the first 10 weeks of grazing on the lightly stocked range pasture. Similarly, although the lightly stocked and heavily stocked range pastures were grazed 25 and 20 weeks respectively in 1976, comparisons of grazing frequency involve only the first 20 weeks of data from the former.

\section{Results and Discussion}

A sample series of photographs of a western wheatgrass tiller are shown in Figure 1. We could determine whether or not a tiller had been grazed between two observation dates, but could not determine whether it had been grazed more than once. Therefore, our estimates of grazing frequency are minimum estimates. Tillers of both western and crested wheatgrass were grazed more frequently under the higher stocking rate in both years (Table 2). Only at the higher stocking rate on crested wheatgrass in 1977 were all tillers grazed at least once; otherwise, $5-22 \%$ of the tillers remained ungrazed at the end of the grazing season. This would seem to constitute a sort of rest-rotation grazing system on an individual tiller basis. With the long grazing season on native range in 1976, some western wheatgrass tillers were grazed five or six times before the season ended or they were completely removed.

Stocking rate had little effect on the proportion of the total available forage removed at each grazing event (Table 3). Only on western wheatgrass in 1977 was the difference between stocking rates significant. Under heavy stocking in 1977 fewer western wheatgrass tillers had $21-40 \%$ of the available forage removed at a

Table 2. Frequency of grazing of western and crested wheatgrass tillers under two stocking rates.

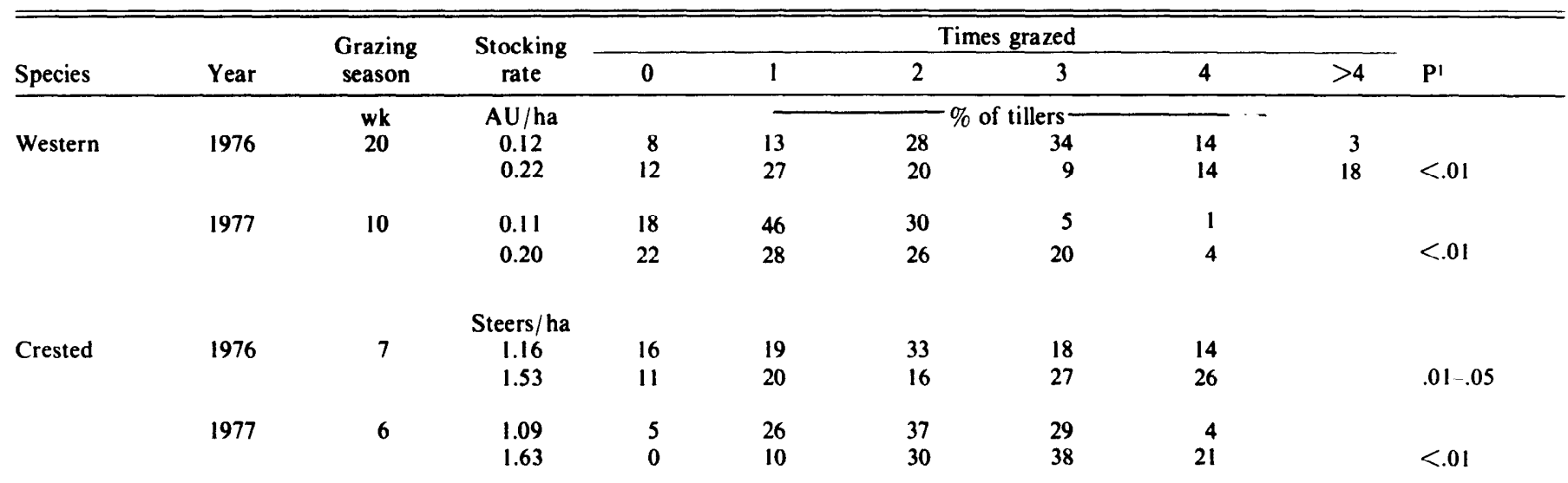

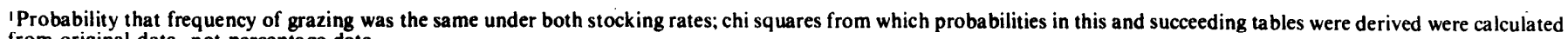
from original data, not percentage data. 


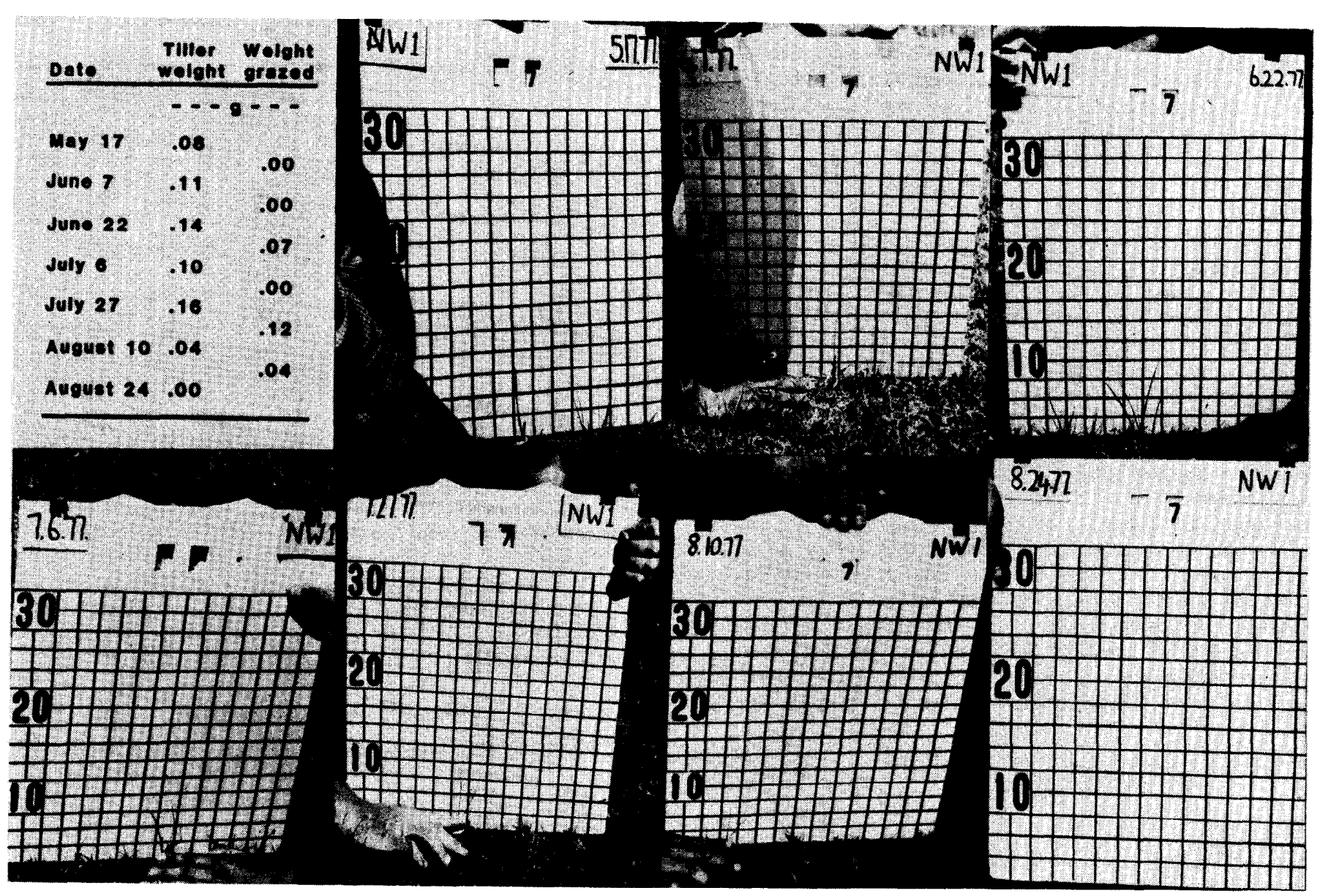

Fig. 1. Western wheatgrass tiller at seven dates, with estimated tiller weight and amount grazed since last date.

single grazing event, and more had $61-100 \%$ removed, than under light stocking. Usually more than $20 \%$ of the forage was removed whenever a tiller was grazed. However, total removal of a tiller was not all that common; removal of more than $90 \%$ of the forage occurred in $10-26 \%$ of the grazing events, depending on species, stocking rate, and year.

Forage removal by grazing followed a totally different pattern from forage removal by clipping. Under grazing, forage was removed from different tillers at different times and in different amounts; some tillers were ungrazed throughout the season and some were completely removed. In contrast, in clipping experiments all tillers are clipped at the same time, all have approximately the same amount of herbage removed, and in some cases nearly all herbage is removed from all tillers. In all the clipping 'studies of western wheatgrass we reviewed, herbage removal was more severe than that we observed under grazing. In the clipping studies, up to $90 \%$ of the current year's growth was removed at each clipping, and all plants were clipped at least once and as often as twelve times per season. It is not surprising that forage production decreased sharply, but the results have little application to grazing conditions. Similar criticism can be directed at the clipping studies of crested wheatgrass.

Forage production of ungrazed western wheatgrass tillers did not differ between years, so data were combined for the two years to increase sample size. In 1977, western wheatgrass tillers grazed once, twice, or more than three times produced significantly more

Table 3. Forage removed from western and crested wheatgrass tillers at two stocking rates.

\begin{tabular}{|c|c|c|c|c|c|c|c|c|}
\hline \multirow[b]{2}{*}{ Species } & \multirow[b]{2}{*}{ Year } & \multirow{2}{*}{$\begin{array}{c}\text { Stocking rate } \\
(\mathrm{AU} / \mathrm{ha})\end{array}$} & \multicolumn{5}{|c|}{$\%$ forage removed per grazing event } & \multirow[b]{2}{*}{$\mathbf{P}^{1}$} \\
\hline & & & $1-20$ & $21-40$ & $41-60$ & $61-80$ & $81-100$ & \\
\hline \multirow{5}{*}{ Western } & & & & & $-\%$ of & events & & \\
\hline & 1976 & 0.12 & 3 & 35 & 28 & 18 & 17 & \\
\hline & & 0.22 & 5 & 31 & 22 & 16 & 26 & $.10-.20$ \\
\hline & 1977 & 0.11 & 5 & 41 & 24 & 8 & 12 & \\
\hline & & 0.20 & 7 & 23 & 28 & 17 & 25 & $<.01$ \\
\hline \multirow[t]{4}{*}{ Crested } & 1976 & 1.16 & 2 & 29 & 24 & 16 & 28 & \\
\hline & & 1.53 & 1 & 34 & 26 & 19 & 20 & $.20-.30$ \\
\hline & 1977 & 1.09 & 1 & 17 & 27 & 19 & 36 & \\
\hline & & 1.63 & 6 & 12 & 22 & 25 & 35 & $.30-.50$ \\
\hline
\end{tabular}


Table 4. Herbage production of western wheatgrass tillers as influenced by stocking rate, length of grazing season, and grazing frequency.

\begin{tabular}{|c|c|c|c|c|c|c|c|c|c|c|}
\hline \multirow[b]{3}{*}{ Year } & \multirow{3}{*}{$\begin{array}{l}\text { Stocking } \\
\text { rate } \\
\text { (AU/ha) }\end{array}$} & \multirow{3}{*}{$\begin{array}{l}\text { Grazing } \\
\text { season } \\
\text { (wk) }\end{array}$} & \multirow{3}{*}{$\begin{array}{c}\text { Times } \\
\text { grazed } \\
\text { (no.) }\end{array}$} & \multirow{2}{*}{\multicolumn{4}{|c|}{ Forage production, $\mathrm{g} /$ tiller }} & \multicolumn{2}{|c|}{$\mathbf{P}^{1}$} & \multirow{3}{*}{$\begin{array}{l}\text { Mean } \\
\text { tiller } \\
\text { weight }(\mathrm{g})\end{array}$} \\
\hline & & & & & & & & \multirow{2}{*}{$\begin{array}{l}\text { Grazed vs. } \\
\text { ungrazed }\end{array}$} & \multirow{2}{*}{$\begin{array}{l}\text { Light } \\
\text { vs. heavy }\end{array}$} & \\
\hline & & & & $.00-.10$ & $.10-.20$ & $.20-.30$ & $>.30$ & & & \\
\hline & & & & & $-\%$ & illers- & & & & \\
\hline Both & Both & - & 0 & 12 & 64 & 21 & 3 & - & - & .17 \\
\hline \multirow[t]{10}{*}{1976} & .12 & 25 & 1 & 11 & 22 & 55 & 11 & $.10-.20$ & $.01-.05$ & .21 \\
\hline & & & 2 & 14 & 64 & 7 & 14 & $.70-.90$ & $.20-.30$ & .18 \\
\hline & & & 3 & 15 & 53 & 21 & 12 & $.70-.90$ & $.30-.50$ & .18 \\
\hline & & & 4 & 5 & 62 & 34 & 0 & $>.90$ & $.70-.90$ & .18 \\
\hline & & & $>4$ & 13 & 31 & 44 & 13 & $.30-.50$ & $.10-.20$ & .21 \\
\hline & .22 & 20 & 1 & 37 & 50 & 14 & 0 & $.20-.30$ & - & .18 \\
\hline & & & 2 & 32 & 68 & 0 & 0 & $.10-.20$ & - & .12 \\
\hline & & & 3 & 35 & 65 & 0 & 0 & $.20-.30$ & - & .12 \\
\hline & & & 4 & 0 & 93 & 7 & 0 & $.50-.70$ & - & .15 \\
\hline & & & $>4$ & 17 & 66 & 17 & 0 & $>.90$ & - & .15 \\
\hline \multirow[t]{8}{*}{1977} & .11 & 21 & 1 & 0 & 8 & 85 & 8 & $<.01$ & $<.01$ & .26 \\
\hline & & & 2 & 10 & 20 & 48 & 21 & $.01-.05$ & $<.01$ & .23 \\
\hline & & & 3 & 0 & 40 & 53 & 8 & $.10-.20$ & $<.01$ & .22 \\
\hline & & & $>3$ & 0 & 12 & 69 & 20 & $<.01$ & $<.01$ & .26 \\
\hline & .20 & 10 & 1 & 35 & 55 & 7 & 3 & $.05-10$ & 一 & .13 \\
\hline & & & 2 & 40 & 44 & 12 & 3 & $.20-.30$ & - & .13 \\
\hline & & & 3 & 32 & 53 & 10 & 5 & $.50-.70$ & - & .14 \\
\hline & & & $>3$ & 0 & 75 & 25 & 0 & $>.90$ & - & .16 \\
\hline
\end{tabular}

'Probability that distribution of forage was same for both populations.

forage than ungrazed tillers (Table 4). In all other cases, there were no significant differences between forage production of grazed and ungrazed tillers. However, forage production of grazed tillers appeared to be consistently less than that of ungrazed tillers on the heavily stocked pastures.

Tillers in the lightly stocked pasture produced more forage than those in the heavily stocked pasture in 1977, regardless of grazing frequency, and more in 1976 when grazed once. Although differences were not significant, there was a trend toward higher forage production under light stocking than under heavy stocking at the higher grazing frequencies in 1976.

Herbage production of crested wheatgrass tillers did not differ significantly between years of stocking rates, so data were combined (Table 5). Tillers grazed twice produced significantly less forage than ungrazed tillers, and tillers grazed at other frequencies appeared to do likewise, although the differences were not significant. There were fewer grazed tillers than ungrazed tillers in the high-producing categories, and more in the class producing $0.05-0.10 \mathrm{~g}$ per tiller.

The mean weight of all tillers in the stand, grazed and ungrazed, can be compared with the mean weight of ungrazed tillers for an overall estimate of the change in herbage production due to grazing. Mean weight of all crested wheatgrass tillers was $0.17 \mathrm{~g}$, a reduction of $16 \%$ from $0.20 \mathrm{~g}$, the mean weight of ungrazed tillers. The change in herbage production of western wheatgrass tillers varied with year and stocking rate. Mean tiller weights and percent change compared to the mean weight, $0.17 \mathrm{~g}$, of ungrazed tillers were, respectively, $0.18 \mathrm{~g}$ and $+9 \%$ under light stocking vs. $0.13 \mathrm{~g}$ and $-26 \%$ under heavy stocking in 1976 and $0.24 \mathrm{~g}$ and $+41 \%$ under light stocking vs. $0.14 \mathrm{~g}$ and $-19 \%$ under heavy stocking in 1977.

It is commonly accepted that forage stands in humid environments are more productive under some intermediate frequency of forage removal than under too severe forage removal or when no forage is removed at all. Examples abound in the literature, but one will suffice. Burton et al. (1963) found that forage production of 'Coastal' Bermudagrass increased as time between clippings increased from 3 to 6 weeks. Clipping every 8 or 12 weeks produced the same amount of forage as clipping every 6 weeks, but clipping only at the end of the growing season produced the smallest forage yield of all. One might expect a similar response from forage stands in less humid environments, although maximum forage production might be attained at a less severe level of forage removal, and in some cases water supply might be insufficient for regrowth.

A number of mechanisms for this response have been suggested: increased tillering; maintenance of optimum LAI; a greater proportion of younger leaves and hence more efficient photosynthesis; removal of older tissues which may lose more dry matter by respiration than they fix by photosynthesis; and allocation of a greater proportion of photosynthate to top growth. The three latter mechanisms and reallocation of photosynthate from other tillers might also account for the greater production per tiller under light grazing than under no grazing. The allocation or reallocation of more photosynthate to top growth should cause a reduction in root growth and root reserves coinciding with any increase in top growth, or a proportionately greater decrease in root growth and reserves when top growth decreases. In clipping experiments with western wheatgrass, Everson (1966) found that clipping decreased top growth 16-59\%, but decreased root growth $86-97 \%$ and root carbohydrate concentration $46-84 \%$, while Branson (1956) reduced forage production by $60-80 \%$ and root growth by $95-98 \%$. Unfortunately, no clipping experiments were found in which top growth was increased, so it was not possible to determine whether this was accompanied by a decrease in root growth.

An important reason for the decrease in forage production of western wheatgrass under heavy stocking and of crested wheatgrass lies in the timing of grazing as well as in the increased

Table 5. Herbage production of crested wheatgrass tillers as influenced by grazing frequency.

\begin{tabular}{|c|c|c|c|c|c|c|}
\hline \multirow{2}{*}{$\begin{array}{l}\text { Times } \\
\text { grazed } \\
\text { (no.) }\end{array}$} & \multicolumn{5}{|c|}{ Forage production, $g$ / tiller } & \multirow{2}{*}{$\begin{array}{l}\text { Mean } \\
\text { tiller } \\
\text { weigh } \\
\text { (g) }\end{array}$} \\
\hline & $.00-.10$ & $.10-.20$ & $.20-.30$ & $>.30$ & $\mathbf{P}^{\prime}$ & \\
\hline & \multicolumn{5}{|c|}{$\%$ of tillers } & \\
\hline 0 & 12 & 44 & 23 & 21 & - & .20 \\
\hline 1 & 23 & 49 & 19 & 9 & $.30-.50$ & .16 \\
\hline 2 & 34 & 48 & 13 & 5 & $.01-.05$ & .14 \\
\hline 3 & 19 & 51 & 25 & 5 & $.05-.10$ & .17 \\
\hline$>3$ & 17 & 57 & 18 & 8 & $.10-.20$ & .17 \\
\hline
\end{tabular}

Probability that distribution of forage production was same for grazed and ungrazed tillers. 
removal of photosynthetic tissue. We started grazing crested wheatgrass just as the culms were beginning to elongate, and many of the growing points were removed before they could produce much forage; these were the tillers tht ended in the 0.05-0.10 g class mentioned above. The same thing happened in the heavily stocked range pastures, where observations of tiller growth did not begin until June 15, 1976 and July 27, 1977, by which time culms of western wheatgrass were beginning to elongate (in 1976) or had already emerged (in 1977).

Our results can be related to those of the grazing studies previously cited. Over both years in our study, utilization of western wheatgrass under light stocking was $65 \%$ and production per tiller was $25 \%$ greater than under no grazing, while utilization under heavy stocking was $75 \%$ and herbage production was decreased $22 \%$. Klipple and Costello (1960) noted that herbage production of western wheatgrass remained the same when utilization of that species increased from about $10 \%$ to about $20 \%$, but declined sharply when utilization increased to $40 \%$. Launchbaugh (1967) found that forage production of western wheatgrass declined from 1410 to 410 to $60 \mathrm{~kg}$ / ha as utilization of the species increased from 44 to 65 to $80 \%$. Reed and Peterson (1961) reported that, as utilization of western wheatgrass increased from 24 to $47 \%$, forage production decreased from 610 to 360 $\mathrm{kg} / \mathrm{ha}$. These grazing studies indicated that decline in stand forage production occurs at somewhere between 20 and $40 \%$ utilization, while our study indicated that decline in production/tiller occurs between 65 and $75 \%$ utilization. This discrepancy would arise if tiller numbers/ unit area decreased faster than production/tiller. In Everson's study of western wheatgrass (Everson 1966), tiller number of plants clipped to $10,7.5,5$, or $2.5 \mathrm{~cm}$ was $99,85,73$, and $51 \%$, respectively of that of unclipped plants, while forage production was $84,64,54$, and $41 \%$ of that of unclipped plants, indicating that production/tiller stayed fairly constant. The rapid reduction in tiller number must reflect the reduction in root growth and reserves noted above.

The rate of forage removal that produces the maximum total forage production is not necessarily the rate which produces the maximum grazed forage. If, for example, maximum forage production is achieved at $20 \%$ utilization, if $90 \%$ as much forage is produced at $30 \%$ utilization, and if utilized forage is the product of production times utilization, the amount of utilized forage under heavy utilization would exceed that under light utilization by .27 to .20 , even though total forage production was reduced. If the high rate of utilization could be maintained without further reduction in stand or productivity, a $35 \%$ increase in utilizable forage would be achieved by a $10 \%$ decrease in total forage production.

Several conclusions can be drawn from our study. First, longinterval time-lapse photography was shown to be a useful tool for studying the effects of grazing on forage production and utilization. Second, the re appeared to be some level of forage removal from western and crested wheatgrass which produced maximum weight per tiller, and this weight may have been greater than the weight per tiller of undisturbed plants. However, this level of forage removal was probably greater than that which produces the inaximum number of tillers per unit area and the maximum forage yield. Maximum forage yield, maximum yield of utilizable forage. and maximum survival may or may not be achieved at the same level of utilization. However, our study has provided a model for a realistic simulation of grazing by clipping, so that these problems can be studied with more precision than was possible formerly.

\section{Literature Cited}

Bedell, T.D. 1973. Clipping effects on growth form, yield, and nutritive quality of crested wheatgrass in eastern Wyoming. Wyoming Agr. Exp. Sta. Res. J. 76. 16 p.

Branson, F.A. 1956. Quantitative effect of clipping treatments on five range grasses. J. Range Manage. 9:86-88.

Burton, G.W., J.E. Jackson, and R.H. Hart. 1963. Effects of cutting frequency and nitrogen on yield, in vitro digestibility, and protein, fiber, and carotene content of Coastal bermudagrass. Agron. J. 55:500-502.

Buwai, M., and M.J. Trlica. 1977. Multiple defoliation effects on herbage yield, vigor, and total nonstructural carbohydrates of five range species. J. Range Manage. 30:164-171.

Carter, J.F., and A.G. Law. 1948. The effect of clipping upon the vegetative development of some perennial grasses. J. Amer. Soc. Agron. 40:10841091.

Everson, A.C. 1966. Effects of frequent clipping at different stubble heights on western wheatgrass (Agropyron smithii Rydb.). Agron. J. 58:33-35.

Gammon, D.M. 1978. Patterns of defoliation during continuous and rotational grazing of rangeland by cattle. Proc. Ist Intl. Rangel. Cong.: 603-605.

Gammon, D.M., and B.R. Roberts. 1978. Patterns of defoliation during continuous and rotational grazing of the Matopos sandveld of Rhodesia. I. Selectivity of grazing. Rhod. J. Agr. Res. 16:117-164.

Greenwood, E.A.N., and G.W. Arnold. 1968. The quantity and frequency of removal of herbage from an emerging annual grass sward by sheep in a set-stocked system of grazing. J. Brit. Grassl. Soc. 23:144-148.

Greenwood, E.A.N., Z.V. Titmanis, and N.A. Campbell. 1974. The effects of defoliation on emergent annual grass swards under simulated grazing. J. Brit. Grassl. Soc. 39:37-45.

Hart, R.H. 1970. Frequency and severity of defoliation of crownvetch stems by grazing sheep. Agron. J. 62:626-627.

Hodgson, J. 1966. The frequency of defoliation of individual tillers in a setstocked sward. J. Brit. Grassl. Soc. 21:258-263.

Hodgson, J., and J.H. Ollerenshaw. 1969. The frequency and severity of defoliation of individual tillers in set-stocked swards. J. Brit. Grassl. Soc. 24:226-234.

Klipple, C.E., and D.F. Costello. 1960. Vegetation and cattle responses to different intensities of grazing on short grass range on the Central Great Plains. U.S. Dep. Agr. Tech. Bull. 1216. 82 p.

Launchbaugh, J.L. 1967. Vegetation relationships associated with intensity of summer grazing on a clay upland site in the Kansas 20- to 24-inch precipitation zone. Kansas Agr. Exp. Sta. Tech. Bull. 154. 24 p.

Lewis, J.K., G.M. Van Dyne, L.R.A. Albee, and F.W. Whetzal. 1956. Intensity of grazing-its effect on livestock and forage production. South Dakota Agr. Exp. Sta. Bull. 459.44 p.

Linehan, P.A. 1952. Use of cage and mower-strip methods for measuring the forage consumed by grazing animals. Proc. VIth Intl. Grassl. Cong. p. 1328-1333.

Reed, M.J., and R.A. Peterson. 1961. Vegetation, soil, and cattle responses to grazing on Northern Great Plains range. U.S. Dep. Agr. Forest Serv. Tech. Bull. 1252. 79 p.

Samuel, M.J., and G.S. Howard. 1982. Botanical composition of summer cattle diets on the Wyoming High Plains. J. Range Manage. 35:305-308.

Santos, G.L., and M.J. Trlica. 1978. Clipping effects on production and carbohydrate reserves of blue grama and western wheatgrass. Proc. 1st Intl. Rangel. Cong. 384-386.

Schmutz, E.M., G.A. Holt, and C.C. Michaels. 1963. Grazed-class method of estimating forage utilization. J. Range Manage. 16:54-60.

Springfield, H.W. 1974. Using a grid to estimate production and utilization of shrubs. J. Range Manage. 27:76-78. 